Т.П. Карташова *

Расчётливое просветительство: П.И. Макушин, И.Д. Сытин и сельские библиотеки Томской губернии в начале XX в.

DOI: $10.31518 / 2618-9100-2018-2-8$

УДК 021(571.16)

Выходные данные для цитирования:

Карташова Т.П. Расчётливое просветительство: П.И. Макушин, И.Д. Сытин и сельские библиотеки Томской губернии // Исторический курьер. 2018. № 2. Статья 8. URL: http://istkurier.ru/data/2018/ISTKURIER-2018-2-08.pdf
Tatiana Kartashova *

\section{Shrewd Charity: Petr Makushin, Ivan Sytin and Rural Libraries in the Tomsk Governorate in the Early 20th Century}

DOI: $10.31518 / 2618-9100-2018-2-8$

How to cite:

Kartashova Tatiana P. Shrewd charity: Petr Makushin, Ivan Sytin and rural libraries in the Tomsk governorate in the early 20th century // Historical courier, 2018, \# 2. Article 8. [Available online:] http://istkurier.ru/data/2018/ISTKURIER-2018-2-08.pdf

Работа выполнена при финансовой поддержке РФФИ и Администращии Томской области, проект № 17-14-70006-ОГН ОГН-Р_СИБ-А

Abstract: In 1916, two booksellers and publishers, two enlighteners Ivan D. Sytin and Petr I. Makushin were congratulated by the whole country on the 50th anniversary of their publishing and social activity. Their fates largely overlapped, their business and warm friendship persisted for many years.

Sytin's publications were widely distributed in the Tomsk province. They sold well in bookstores, Tomsk libraries purchased them actively, and rural libraries of the Tomsk province would have them. Petr Makushin created a public organization called «Society for the Promotion of the Free Rural Libraries in Tomsk Governorate» to introduce books into village, which was established in 1901. During 1902-1919, the Society opened about 600 free public libraries. It was only in large towns that metropolitan book publishers could enter the Siberian book market on their own; promoting books in the Tomsk countryside was possible only through Petr Makushin and his Society for the Promotion.

The library network in the Tomsk province arose due to the personal initiative and private investment. Petr Makushin succeeded in establishing strong ties with the central publishers, including Sytin's firm, which allowed to reduce significantly book prices, receive discounts, installments, to attract investments from the center. 62 metropolitan firms participated in providing books for rural libraries, but contributions made by Ivan Sytin were the most impressive. State officials who governed Siberia in the absence of zemstvo in the region, practiced fiscal austerity that did not let establish libraries. Makushin succeeded in creating a regional model of library development at minimal cost, using and adapting the experience accumulated in European Russia to local conditions.

Keywords: book trade; cultural-enlightening society; free public library; Siberia; Tomsk province; Petr Ivanovich Makushin; Ivan Dmitrievich Sytin.

The article has been received by the editor on 28.09.2018.

Full text of the article in Russian and references in English are available below.

\footnotetext{
* Карташова Татьяна Петровна, канд. ист. наук, старший научный сотрудник научно-хранительского отдела Томского областного краеведческого музея имени Михаила Бонифатьевича Шатилова (Россия), е-таil: kartashova67@yandex.ru

Kartashova Tatiana Petrovna, PhD in History, Senior researcher, Tomsk Museum of Local History (Russia), e-mail: kartashova67@yandex.ru
} 
Аннотация: В 1916 г. вся страна поздравляла двух книгопродавцев и издателей, двух просветителей И.Д. Сытина и П.И. Макушина с 50-летием книгоиздательской и общественной деятельности. Их судьбы во многом пересекались, а деловые и теплые дружеские отношения сохранялись на протяжении долгих лет.

Сытинские издания имели широкое распространение в Томской губернии. Они хорошо продавались в книжных магазинах, активно приобретались томскими библиотеками, поступали в сельские библиотеки губернии. Для продвижения книг в деревне П.И. Макушиным была создана общественная организация «Общество содействия устройству сельских бесплатных библиотек-читален в Томской губернии», открытие которой состоялось в 1901 г. За 1902-1919 гг. обществом было открыто около 600 бесплатных народных библиотек. Самостоятельно проникнуть на сибирский рынок столичные книгоиздатели могли только в крупных городах Сибири, продвижение книжной продукции в сельской местности Томской губернии было возможно только через П.И. Макушина и его Общество содействия.

Библиотечная сеть в Томской губернии возникла благодаря личной инициативе и частным капиталовложениям. П.И. Макушину удалось наладить прочные связи с книгоиздателями центра и с фирмой И.Д. Сытина в том числе, что позволило значительно удешевить книгу, получать скидки, рассрочку, привлечь инвестиции из центра. В пополнении сельских библиотек участвовали 62 столичные фирмы, но отчисления, сделанные И.Д. Сытиным, были самыми внушительными. При отсутствии земства управление краем осуществлялось государственными чиновниками в режиме жесткой экономии средств. Макушину удалось создать региональную модель библиотечного развития при минимальных затратах, используя и адаптируя к местным условиям накопленный в Европейской России опыт.

Ключевые слова: книжная торговля; культурно-просветительное общество; народная бесплатная библиотека; Сибирь; Томская губерния; Пётр Иванович Макушин; Иван Дмитриевич Сытин.

\section{Томско-московское содружество}

В 1916 г. 50-летие книгоиздательской и общественной деятельности отмечали два известных в России и за ее пределами книгопродавца и издателя, два просветителя: И.Д. Сытин и П.И. Макушин. Юбиляров поздравляла вся страна. В Москве к юбилею И.Д. Сытина вышло специально подготовленное литературно-художественное издание, в котором участвовали М. Горький, А.П. Чехов, А.И. Куприн, Н.А. Рубакин и другие деятели культуры (около 200 авторов) ${ }^{1}$. Сразу несколько юбилейных изданий, посвященных П.И. Макушину, вышло в Томске: от сотрудников его фирмы, городского самоуправления и духовенства губернии ${ }^{2}$. Поздравляли и сами юбиляры друг друга. Вот слова П.И. Макушина: «Одаренный необычайной энергией, острым умом, организаторским талантом, любовью к народу, Иван Дмитриевич Сытин сумел собрать около себя кружок хороших людей, объединить их и при их помощи, вместо лубочной, глупой, литературы, создать хорошую народную книгу... Как издатель и как умный энергичный распространитель печатного слова, он оказал громадную неоценимую услугу делу просвещения в России. Глубоко чту его, как

1 Полвека для книги. Литературно-художественный сборник, посвященный 50-летию издательской деятельности И.Д. Сытина. 1866-1916. М.: Тип. Т-ва И. Сытина, 1916. 610 с., фронт., 44 л. ил.

${ }^{2}$ Крекнин Г.Я. Ревнитель света - П. И. Макушин: 50 лет просветительской деятельности в Сибири, 1866-1916 гг. Томск : Издание служащих и рабочих П. И. Макушина, 1916. VIII,103 с.; Полувековой юбилей П.И. Макушина. 25. III. 1866-1916 г. / Изд. Том. городского общественного управления. Томск, 1917. [2], 177 с.; Ливанов И.А. Полвека на просвещение Сибири: чествование П. И. Макушина духовенством, духовноучебными заведениями и учреждениями по поводу 50-ти летия его общественно-просветительной деятельности. Томск, 1916. [4], 41 с. 
редкого ревнителя народного просвещения и преклоняюсь пред его железной энергией и плодотворной полувековой деятельностью» ${ }^{1}$.

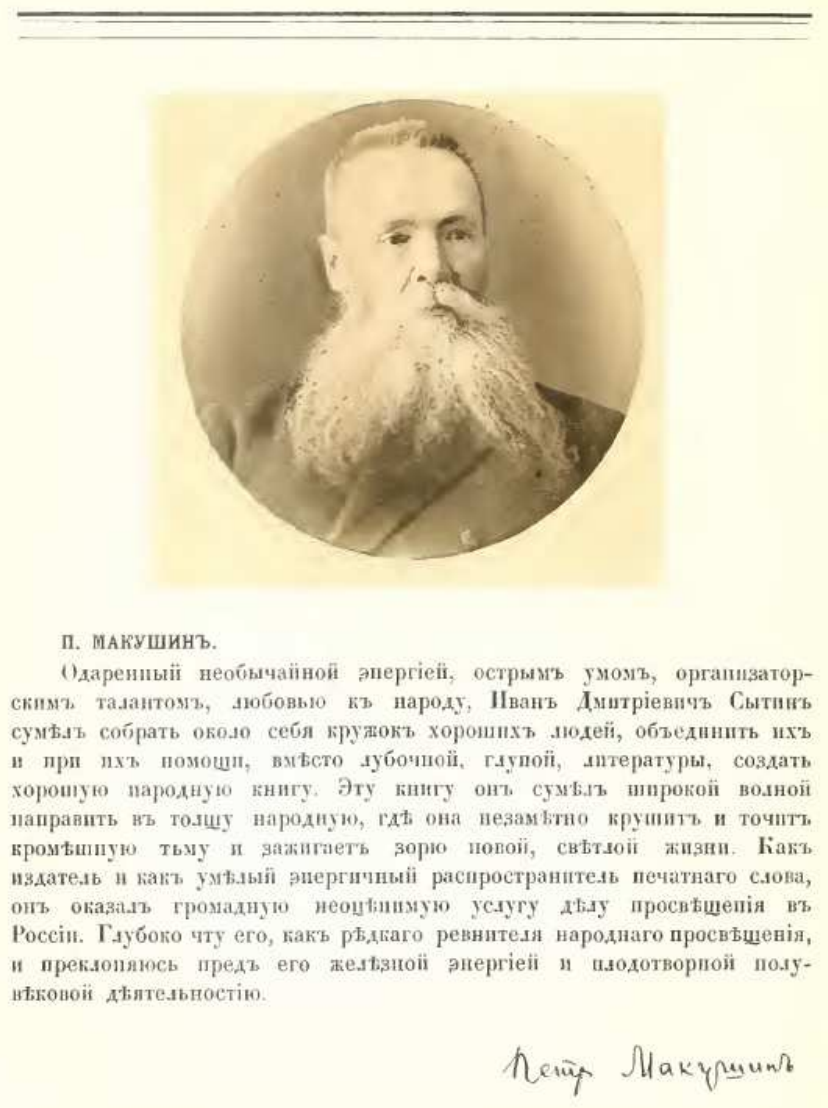

Поздравление И.Д. Сытину от П.И. Макушина.

В еженедельном иллюстрированном художественно-литературном журнале «Искры» (издатель «Т-во И. Д. Сытина») была опубликована статья «Гражданин-просветитель» с большим портретом П. И. Макушина: «25 марта исполнилось 50 лет общественной и просветительной деятельности П. И. Макушина, самого крупного и самого деятельного общественного работника в Сибири. Всю свою жизнь он посвятил прекрасному служению народу, его просвещению и образованию. С кличем «Ни одного неграмотного» он начал свою огромную программу деятельности и в течение 50 лет достиг таких блестящих результатов, что слава его имени давно прошла за пределы Сибири»².

Пересечению их судеб и совпадению некоторых дат в жизни просветителей можно посвятить отдельное крупное исследование. Оба они начинали бизнес с нуля, на заемные капиталы. Занимались издательской и книготорговой деятельностью, издавали популярные газеты: «Сибирскую жизнь» в Томске и «Русское слово» в Москве. Оба печатали книги,

\footnotetext{
${ }^{1}$ Полвека для книги. С. 84.

${ }^{2}$ Гражданин-просветитель // Искры. М., 1916. № 13. 27 марта. С. 101.
} 
календари, открытки, получая за высокое качество исполнения медали, дипломы и награды. Издавали дешевые книги для народного чтения. Хорошо знали вкусы и разбирались в психологии народа, моментально реагировали на покупательский спрос. После национализации всего имущества оба остались до конца своей жизни на рабочем посту, оказали немалые услуги советской власти в восстановлении книготорговли и книгоиздания. В последние годы жизни они писали мемуары, часть из которых была издана ${ }^{1}$.

И главное: оба они умели сочетать благородные мотивы с коммерческой успешностью. И если И.Д. Сытин первым доказал возможность массового издания серьёзных книг для народа, то П.И. Макушину принадлежит честь создания системы продвижения этих книг в народ за счёт сельских библиотек. Об этой системе и пойдёт речь в статье. Важнейшая её черта - привлечение широкого круга общественных сил, готовых участвовать в новом деле деньгами, своей продукцией, личными усилиями. Один из столпов системы П.И. Макушина - объединение сил сибирских просветителей и издателей Европейской России, из них же важнейший - И.Д. Сытин.

Деловые связи и теплые дружеские отношения двум издателям-просветителям удалось сохранить на долгие годы, о чем остались многочисленные свидетельства в личном фонде П.И. Макушина, хранящемся в Томском областном краеведческом музее. Здесь находятся письма и поздравительные адреса от И.Д. Сытина за разные годы. На празднование 25-летия общественной деятельности П.И. Макушина в Сибири 25 марта 1891 г. И.Д. Сытин писал: «Ермак покорил Сибирь оружием, Вы покоряете её книгой» ${ }^{2}$. В тот день, - писал далее в мемуарах Петр Иванович, - я получил приветственные телеграммы и письма почти от всех книготорговцев... Характерно, что почти все поздравители вслед за благопожеланиями нашли нужным отметить мою аккуратность в расчетах и ставили мне это в какую-то особую заслугу. Это невольно давало повод думать, что аккуратность в расчетах не была обычным явлением в среде столичных книготорговцев с провинциальными...»³.

В поздравлении от фирмы И.Д. Сытина с 25-летием открытия книжного магазина в 1898 г. читаем: «Правление Товарищества всегда считало и считает для себя весьма приятным долгом выразить Вам, Многоуважаемый Петр Иванович, свою глубочайшую признательность за Вашу полнейшую добросовестность в торговых сношениях с нашей фирмой за весь период торговли, правильность и аккуратность расчетов, производимых Вами всегда с соблюдением установленных между нами сроков платежа и убедительно просит и в будущем не обходить Вашим вниманием нашу фирму, всегда готовую исполнить Ваши требования» ${ }^{4}$.

В 1889 г. благодаря И.Д. Сытину происходит встреча П.И. Макушина с Л.Н. Толстым в Ясной Поляне, о чем Петр Иванович оставил воспоминания: «Л.Н. Толстой через И.Д. Сытина передал мне о своём желании повидаться со мной. Лестное для меня внимание ${ }^{5}$ было с удовольствием мною исполнено. В один из вечеров И[ван] Д[митриеви]ч повез меня к нему в дом, находившийся в Хамовниках... Одетый в тёмную блузу, подпоясанный ремнём Л[ев] Н[иколаевич] встретил И[вана] Д[митриеви]ча словами: "Вы привезли ко мне Вашего сибиряка! Очень рад познакомиться". Усадив нас на стулья, а сам поместившись в кресле перед письменным столом, начал с объяснения, что желание видеть меня появилось у него вследствие рассказов И[вана] Д[митриеви]ча о моей просветительской деятельности в Сибири. Пришлось поделиться с ним и тем, что сделано, и планами на будущее. Слушая меня, он выражал своё одобрение словами "прекрасно", "это хорошо", "это разумно". Темой

\footnotetext{
1 Жизнь для книги: И.Д. Сытин. Страницы пережитого: Современники о И. Д. Сытине. М.: Книга, 1978. 352 с.; Макушин П.И. К пятидесятилетию книготорговли в Сибири. (Из воспоминаний П.И. Макушина). Новониколаевск, 1923. 22 с.; Макушин П.И. Газетно-издательская деятельность во времена царизма: Глава из воспоминаний // Северная Азия. 1928. Кн.2. С. 91-100.

2 Томский областной краеведческий музей (далее-ТОКМ). Личный фонд П.И. Макушина. ТОКМ 10992/7. Л. 15a.

${ }^{3}$ Там же.

4 TOKM 10992/85.

5 Так в тексте.
} 
разговора была тьма народная и пьянство и средства борьбы с тем и другим. Беседа продолжалась около часа» ${ }^{1}$.

В 1895 г. почти одновременно отдельным изданием в Москве и в Томске выходит рассказ Л.Н. Толстого «Хозяин и работник». Для Томска того времени тираж был довольно большим - 3000 экземпляров. Цена книжки составляла всего 10 копеек и была вполне доступна широкой читающей публике 2 .

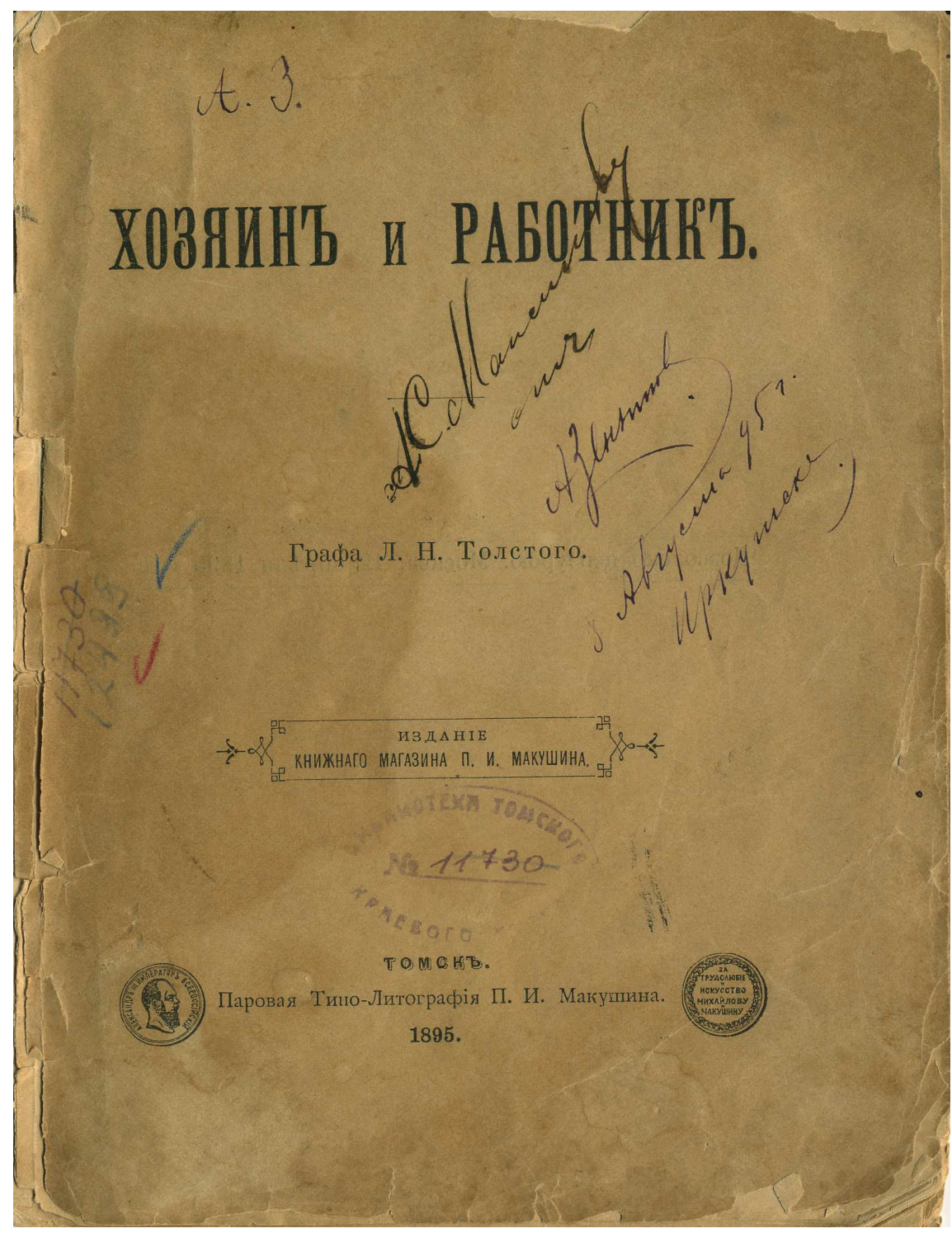

Обложка книги Л.Н. Толстого, изданной в томской типо-литографии П.И. Макушина, с дарственной надписью, выполненной в Иркутске (Томский областной краеведческий музей)

Сытинскими изданиями успешно торговали книжные магазины г. Томска, их активно приобретали томские библиотеки, в том числе и общественная библиотека «Дома науки». Хотя устав Народного университета в г. Томске официально был утвержден лишь 9 января 1916 г., уже в конце 1913 г. библиотека «Дома науки им. П.И. Макушина» располагала солидным книжным фондом. В двух томах рукописного каталога библиотеки числится 6196

\footnotetext{
${ }^{1}$ Колосова Г.И. «Свидание с Толстым»: из воспоминаний П. И. Макушина // Лев Толстой и время. Томск, 2001. С. 251-252.

2 Толстой Л.Н. Хозяин и работник: Рассказ. М.: Тип. И.Д. Сытина, 1895. 96 с.; Толстой Л.Н. Хозяин и работник / Кн. магазин П.И. Макушина. Томск: Тип. П.И. Макушина, 1895. 63 с.; Карташова Т.П. Томские издания произведений Л.Н. Толстого // Лев Толстой и время. Томск: Изд-во Том. ун-та, 2010. С. $253-257$.
} 
номеров книг ${ }^{1}$. Они поступали в библиотеку из разных книгоиздательств с 1912 по 1917 гг.: от И.Д. Сытина, П.П. Сойкина, А.Д. Ступина, П.В. Луковникова, А.С. Панафидиной, Л.Ф. Пантелеева, издательств «Знание», «Научное слово», «Наука», «Школа» и многих других.

Основной массив поступлений относится к 1912-1914 гг. - это время сразу после открытия «Дома науки». И только от И.Д. Сытина продолжали поступать книги и в 1915, и в 1916, и в 1917 году. Всего из 6196 номеров 1683 было получено от И.Д. Сытина. На репертуаре присланных И.Д. Сытиным книг отразилось тематическое разнообразие продукции его фирмы. Это учебники и учебные пособия для взрослых и детей по истории, химии, математике, астрономии, физике, зоологии, ботанике, географии, буквари и хрестоматии, общественно-политическая литература, русская и зарубежная классика: А.С. Пушкин, Н.А. Некрасов, А.С. Грибоедов, Ф.М. Достоевский, Э. Гофман, В. Гюго, Г. Гауптман, Г. Уэллс, Р. Киплинг, В. Скотт.

Тематический разброс иногда вызывает улыбку, особенно когда читаешь названия книг, расположенных в каталоге одна за другой: «Старообрядческий начальный учебник по Закону Божию» Н.П. Розанова (М., 1908); «Руководство френологии, хиромантии, графологии и т.П.» Г. Кузьмина и П. Ржанициной (М., 1910); «О том, как надо жить, чтобы быть здоровым. Беседы по гигиене» В. Рахманова (М., 1900); «Как лечить лошадь» и «Как лечить корову» Г. Гирина (М., 1902). От фирмы И.Д. Сытина были получены популярные в то время и широко востребованные пособия и справочники для проведения народных чтений и сеансов кинематографа: «Сборник чтений с волшебным фонарем в школе и дома» (М., 1904); «Кинематограф - его происхождение, устройство, современное и будущее общественное и научное значение» В. Готвальта (М., 1909).

В большом количестве сытинские издания поступали и в сельские библиотеки Томской губернии, открытые благодаря макушинскому Обществу содействия устройству сельских библиотек-читален в Томской губернии. В пополнении библиотек участвовали 62 фирмы², согласившиеся отчислять на сельские библиотеки 5\% со всех книг, проданных в магазине П.И. Макушина. С 1910 по 1915 гг. включительно было перечислено 9336 р. 22 к. Среди них - фирма М.О. Вольфа (361 р. 6 к.), «Посредник» (240 р. 97 к.), А.Ф. Девриен (396 р. 53 к.), Ф.В. Эттингер (800 p. 56), т-во «Просвещение» $(272$ р. 64 к.), А.Д. Ступин (397 р 44 к.), А.С. Суворин (303 р., 71), Д.И. Тихомиров (479 р.13 к.) и другие. На этом фоне резко выделяется сумма отчислений, сделанных И.Д. Сытиным - 2201 р. 82 к. ${ }^{3}$ Эта цифра прежде всего говорит об очень большом размере книготорговых операций между фирмами.

\section{Бесплатные библиотеки}

Продвижение столичных изданий в провинции, в неземской части России, роль крупного книгоиздательского и книготоргового бизнеса в формировании библиотечной сети в Сибири в период ее ускоренного капиталистического развития в начале XX в. - тема достаточно новая и малоизученная. Постановкой и началом изучения данной проблемы можно считать исследование Ю.В. Тимофеевой, в котором рассматривается привлечение П.И. Макушиным столичных издателей и книгопродавцев к открытию и комлектованию народных бесплатных библиотек в Томской губернии ${ }^{4}$. Несмотря на появление обобщающих работ по истории

\footnotetext{
${ }^{1}$ Хронологический каталог библиотеки «Дома науки» им. П.И. Макушина. Кн. № 1-2. Томск, 1912 г. 268, 118 л. (Рукопись. Томский обл. краеведческий музей. ТОКМ 10992/428-429).

2 Участие книгопродавцев и издателей в учреждении народных библиотек-читален в Томской губернии. Томск, 1916. С. 5-7.

3 Там же. С. 7.

${ }^{4}$ Тимофеева Ю.В. Источники финансирования библиотек, учрежденных с помощью Общества содействия устройству сельских бесплатных библиотек-читален в Томской губернии (1901-1919 гг.) // Библиотековедение. 2018. Т. 67, № 1. C. 91-101. DOI: 10.25281/0869-608X-2018-67-1-91-101.
} 
книжной культуры в Азиатской России ${ }^{1}$ и монографий, посвященных вопросам образования и грамотности, чтению крестьян и роли книги в культуре и быту сельского населения Сибири ${ }^{2}$, вопрос о том, что было определяющим - читательские интересы крестьян или ассортимент печатной продукции у книготорговцев, - до сих пор остается открытым ${ }^{3}$. Как уже было замечено Ю.В. Тимофеевой, развитие книговедческих исследований долгое время ограничивалось рамками Европейской России, а сибирский регион рассматривался как единое целое. Большая часть выводов о культуре чтения и развитии сибирских библиотек делалась на основе материалов по Восточной Сибири ${ }^{4}$. Дальнейшее, более углубленное исследование механизмов открытия и функционирования народных библиотек в селах за Уралом позволяет сделать вывод о наличии своей специфики практически в каждой сибирской губернии. Губернии различались долей участия государства, общественных организаций и бизнеса в создании библиотек, разными были источники финансирования, имелись также нюансы в толковании законодательства.

К началу XX в. в России был накоплен уже значительный земский опыт создания библиотечных сетей. Так, Вятское губернское земство в 1894 г. ассигновало 15000 р. на открытие 3000 библиотек, по одной в каждом сельском обществе. Эти «пятирублевые» библиотеки послужили первоначальным ядром народно-библиотечного дела в Вятской губернии. Харьковское общество грамотности при субсидии со стороны губернского земства к 1 января 1907 г. имело 427 сельских библиотек. В 1910 г. в Вологодской губернии было 897 библиотек, в Воронежской - 719, Пермской - 556. Олонецкое, Вологодское, Московское и другие земства приступили к выработке библиотечных сетей с целью равномерного распределения библиотек по территории губернии ${ }^{5}$. Но это был земский опыт. В Сибири земство до революции так и не появилось.

Ещё один путь распространения книг в российской глубинке - создание школьных библиотек. Государство российское в начале XX в. уже приняло курс на ускоренное развитие начального образования, вложения в развитие школьной сети возрастали опережающим темпом по отношению к другим отраслям бюджета. Но разных регионов новый курс коснулся в разной степени. В Сибири из-за редкого населения и больших расстояний сам принцип, разработанный земскими деятелями центра - школа через 3 версты, районная библиотека для нескольких сел - был абсолютно неприменим. В газете «Сибирская жизнь» как анекдот рассказывался случай, описанный в хабаровской газете «Приамурье», когда местное учебное начальство получило министерское распоряжение об установлении «сети школ» через каждые 3 версты, причем забота об устройстве этих школ стоимостью в 500 руб. всецело возлагалась на местные самоуправления. «Если министерскую сеть применить к нашей окраине, где, между прочим, нет самоуправления, - пишет газета, - то при министерской норме школьной сети требуется свыше 60.000 школ и, следовательно, свыше 30 миллионов рублей на одну только их постройку» ${ }^{6}$. Для сравнения приведем томские «масштабы»: к 1911 г. в Томской губернии одна школа приходилась на 438 кв. верст ${ }^{7}$ Понятно, что земские нормы совершенно не подходили к сибирским условиям, а правительственные дотации на школы МНП считались «непроизводительными» (на одного учащегося в школе МНП тратилось 17 руб. 30 к., а в ведомстве Св. Синода 8 руб. 54 к. в

\footnotetext{
${ }^{1}$ Очерки истории книжной культуры Сибири и Дальнего Востока. Новосибирск, 2000. Т. 1. 316 с.; 2001. Т. 2. $367 \mathrm{c}$.

2 Зверева К. Е., Зверев В. А. Как Сибирь училась читать: школа, грамотность и книга в Русской деревне конца ХІХ - начала ХХ века. Новосибирск: НГПУ, 2013. 237 с.; Тимофеева Ю. В. Книжная культура сельского населения Западной Сибири (конец XIX - начало XX в.). Новосибирск, 2012. 192 с.

3 Тимофеева Ю.В. Книжная культура сельского населения Западной Сибири конца XIX - начала XX в.: историография вопроса // Известия Алтайского гос. ун-та. 2010. № 4/1. С. 250.

${ }^{4}$ Там же.

${ }^{5}$ Серополко С.Ф. Внешкольное образование. Сб. ст. М., 1912. С. 37-40.

${ }^{6}$ Сибирская жизнь. 1908. № 66, 1 апр.

${ }^{7}$ Виноградов П.Т. Краткий очерк начального образования в Томской губернии в 1910 г. Томск, 1912. С. 2.
} 
год) $)^{1}$. Поэтому в селах губернии повсеместно открывались церковно-приходские школы и школы грамоты как наиболее экономный и приемлемый вариант.

В 1909 г. только на развитие внешкольного и дошкольного образования по Томской губернии у центра испрашивалось ежегодных ассигнований 41000 руб. и единовременных 110950 руб. ${ }^{2}$ Народные библиотеки предполагалось открыть в 50-ти пунктах, с платой каждому библиотекарю по 120 руб. в год. По такому расчету ежегодно требовалось 9000 руб., и единовременные затраты на обзаведение должны были составить 2500 руб. (по 50 руб. на библиотеку) ${ }^{3}$. Требуемых сумм в полном объёме Сибирь не получила. Но те деньги, которые всё же выделялись, расходовались и через Общество содействия. В 1910 г. Обществом содействия было получено от Министерства народного просвещения 200 руб. субсидии для развития библиотечного дела на селе, а с 1911 г. ежегодно выделялось по 300 руб. Так вместо 9000 руб. в год на 50 библиотек экономные чиновники потратили всего 300 руб. и отчитались об открытии в 1913 г. 63 библиотек ${ }^{4}$ Было ясно, что государство не готово пока стать ведущей силой в развитии сибирской библиотечной сети.

В этих условиях резко возрастала роль частных предпринимателей и городских обществ. Из личной инициативы П.И. Макушина родилось и Общество содействия устройству сельских бесплатных библиотек-читален в Томской губернии. По официальной версии, предложенной П.И. Макушиным и принятой безоговорочно всеми исследователями, идея создания библиотечного общества возникла у него, когда он во время инспекционной поездки в 1899 г. в селения Томского уезда, вместе со штатным смотрителем П.А. Буткеевым, увидел огромный рецидив неграмотности у окончивших сельскую школу. Основной причиной повторной неграмотности являлось отсутствие в сельской местности книг для чтения (к 25 годам жизни 85 \% окончивших начальную школу совершенно разучивались читать $)^{5}$. При отсутствии книг в деревне все затраты на образование становились бесполезными. Получалось, что государство и местное население затрачивало большие средства на народное образование с нулевым результатом. Именно это явление и послужило П.И. Макушину доводом в пользу создания новой общественной организации, деятельность которой достаточно обстоятельно изучена ${ }^{6}$.

Книг на селе было явно недостаточно, а народные библиотеки стали массово появляться лишь в начале XX в., но не следует считать сибирскую деревню рубежа XIX-XX вв. совершенно безграмотной и бескнижной. Широкому развитию светских народных бесплатных библиотек в сельской местности Сибири препятствовало не безразличие населения, а естественные природно-климатические и географические условия, целый комплекс мер правительства, направленный на «убережение народа» от пагубного влияния антиправительственной и антирелигиозной пропаганды, а также отставание «окраины» в правовом отношении.

\section{Расчёт и благотворительность}

Итак, инициатива П.И. Макушина не выглядит оторванной от жизни. Однако в первые 7 лет деятельность Общества содействия развивалась очень медленно. В 1902 г. было открыто только 2 библиотеки, в 1903 - 13, в $1904-7$, в 1905 - 16, 1906 - 6, в 1907 - 5, в 1908 - 15, а

\footnotetext{
1 Там же. С. 3.

${ }^{2}$ ГАТО. Ф. 126. Оп. 3. Д. 495. Л. 17 об.

${ }^{3}$ Там же.

${ }^{4}$ ГАТО. Ф. 126. Оп. 2. Д. 2943. Л. 200.

5 Участие книгопродавцев. С. 1.

6 Пронина М.Г. Общество содействия устройству сельских бесплатных библиотек-читален в Томской губернии // Книжное дело Сибири и Дальнего Востока в XIX - XX веках. Новосибирск, 1986. С. 39-50; Тимофеева Ю.В. Библиотеки Общества содействия устройству сельских бесплатных библиотек-читален в Томской губернии (1901-1919 гг.) // Библиотековедение. Москва, 2017. Т. 66, № 4. С. 443-450.
} 
всего за 7 лет -64 библиотеки ${ }^{1}$. Это значило, что библиотеки оставались в томской деревне диковинкой.

П.И. Макушин искал средства переломить положение дел. Первый его шаг, как будто, укладывается в рамки привычных представлений о купеческой благотворительности. В 1908 г. П.И. Макушин в 1908 г. основал особый фонд - «Капитал для устройства сельских бесплатных библиотек в Сибири», пожертвовав в него 31.200 руб. Эти деньги были положены в банк под $6 \%$ годовых, а право распоряжениям ими передано томскому городскому самоуправлению, с условием, что часть получаемых процентов должна расходоваться на сельские библиотеки в Томской губернии: в первые 10 лет - по 750 руб. в год, во вторые 10 лет - по 1500 руб. и в третьи 10 лет - по 2000 руб. в год. ${ }^{2}$ Пожертвования в таком виде нередко делались на сиропитательные дома, на гимназии и училища. Некоторая необычность замысла П.И. Макушина - в том, что часть процентов предполагалось использовать на увеличение самого капитала, так что через сто лет капитал должен был вырасти до миллиона рублей. Предполагалось, что в это время деньги будут использоваться не только в Томской губернии, но и в Тобольской, Енисейской, Иркутской губерниях, Акмолинской и Семипалатинской областях. Речь, таким образом, шла не о единоразовом широком жесте, но о продуманной стратегии библиотечного строительства целого региона на период по крайней мере до 1938 г.

Наличие неприкосновенного капитала позволяло проявлять гибкость и быть уверенным в завтрашнем дне, а на текущие расходы П.И. Макушин находил самые разные источники доходов: от активизации собственных внутренних ресурсов (подписка, сбор продуктами) до привлечения столичных и иностранных инвестиций и пожертвований. Первое значительное денежное пожертвование (в 500 руб.) поступило при открытии общества в 1901 г. от самого П.И. Макушина. В 1904 г. - пособие в 500 руб. от Томского губернского попечительства о народной трезвости. Это пособие оказывалось потом ежегодно, исключая 1906 и 1907 гг. По распоряжению попечителя Западно-Сибирского учебного округа, Совету выдано пособие в 1910 г. - 200 руб., в 1911 и 1912 гг. - 300 руб.

Но главная часть системы, созданной П.И. Макушиным - это участие коллег по цеху. С 1910 г. Обществу оказывалась ценная поддержка со стороны почти всех крупных книгопродавцев, имевших торговые сношения с Томским книжным магазином П.И. Макушина. В тот год на собрании книготорговцев в Москве, а затем в СанктПетербурге, П.И. Макушин сделал доклад об Обществе содействия, его задачах и достигнутых результатах, закончив сообщение таким воззванием: «Бессильный собственными и местными средствами удовлетворить указанную нужду, я, состоя в течение 36 лет членом почтенной семьи российских книгопродавцев, обращаюсь к товарищам по профессии с покорнейшею просьбою помочь мне в деле внедрения книги в забытой Сибири, не имеющей до сего времени земского самоуправления...» ${ }^{3}$. На призыв о пожертвовании книг и 5\% отчислений с оборотов откликнулись 62 книгоиздательские и книгопродавческие фирмы, о чем уже было сказано выше. Участие книгопродавцев и издателей в деле устройства народных библиотек в Томской губернии способствовало их росту. В 1910 г. было открыто 65 библиотек, в 1911 г. - 58, в 1912 г. - 64, в 1913 г. - 59, в 1914 г. - 51 и в 1915 г. - 54 библиотеки. Таким образом, за 6 лет в губернии была открыта 351 библиотека.

В историографии принято рассматривать взносы книгоиздателей в фонд Общества содействия как благотворительную помощь, и заслугой П.И. Макушина считать то, что ему удалось привлечь благотворителей. Это верно отчасти: в том, что касается частных лиц, делившихся своими рублями и копейками. Но со стороны книгоиздателей действовал и

\footnotetext{
${ }^{1}$ Участие книгопродавцев... С. 1.

${ }^{2}$ Сибирская жизнь. 1907. № 170, 21 дек.

3 Цит. по: Тимофеева Ю.В. Источники финансирования библиотек, учрежденных с помощью Общества содействия устройству сельских бесплатных библиотек-читален в Томской губернии (1901-1919 гг.) // Библиотековедение. 2018. Т. 67, № 1. С. 91-101. DOI: 10.25281/0869-608X-2018-67-1-91-101. C. 94.
} 
коммерческий расчёт. Дело в том, что самостоятельно проникнуть на необъятный сибирский рынок столичные книгоиздатели могли только в крупных городах. Продвижение книжной продукции в сельской местности Томской губернии было возможно только через П.И. Макушина и его Общество содействия.

Если в селах Европейской России активно развивалась стационарная книжная торговля, повсеместно открывались земские книжные склады и магазины, то в Сибири не было ни того, ни другого. Далеко не во всех селах были даже почтовые отделения связи. Большие расстояния, низкая плотность населения и недостаточно развитая транспортная система способствовали тому, что стационарная торговля приносила убытки. В 1896 г. П.И. Макушин попытался организовать так называемые лавки-шкапы в деревне, но за 5 лет существования они принесли убыток в 10000 руб., а книги были расхищены либо утеряны ${ }^{1}$. Поэтому основной формой распространения книги в сибирской глубинке стали народные и ученические библиотеки, на что уже неоднократно указывали исследователи ${ }^{2}$.

Доставка книг в села губернии была делом очень непростым, даже после строительства Транссиба. Больше всего проблем для книгораспространения создавала удаленность многих населенных пунктов от губернского центра и друг от друга. В 1913 г. заведующий Красноярским училищем (Змеиногорский уезд) А. Иванов сообщает в Общество содействия о способах пересылки книг для народной библиотеки: «Я очень рад, что имеется возможность возродить нашу библиотеку. Но, к сожалению, прямого попутчика для перевозки книг найти нельзя. Можно их переправить конторой братьев Каменских в Семипалатинске, а тут 160 верст и очень часто ездят попутчики. И еще лишь летом через пароходские агенства» ${ }^{3}$. Вот почему пожелание П.И. Макушина о добровольных отчислениях должно было выглядеть для столичных издателей не униженной просьбой, но деловым предложением. Конечно, то, что знаменитый издатель И.Д. Сытин деятельно поддержал предложение П.И. Макушина, придавало этому предложению дополнительную силу.

Предложение это имело тем большую ценность, что сибирский рынок стремительно расширялся именно в это время. Вызванные строительством Транссибирской магистрали высокие темпы экономического роста, переселенческое движение в Сибирь, возникновение новых населенных пунктов сопровождались строительством новых школ, церквей, открытием библиотек. Изменялся состав сибирского населения и уровень его грамотности. Именно в сельскую местность хлынули потоки переселенцев из Европейской России, Украины, Прибалтики, большая часть которых осела в Томской губернии. Для них в первую очередь и открывались библиотеки.

Наконец, работа через посредничество П.И. Макушина была выгодна и за счёт его способности получать то, чего другим добиться не удавалось. Накануне Первой мировой войны сельское население Томской губернии все чаще проявляло не только инициативу в вопросах финансирования библиотек, но и самостоятельность при их учреждении. Так, в 1913-1914 гг. напрямую губернатору, минуя Общество содействия, направляли свои ходатайства уездные училищные советы, общества трезвости, кредитные и потребительские товарищества. Но процедура открытия таких библиотек почти всегда затягивалась. Самостоятельные (помимо П.И. Макушина) ходатайства гораздо чаще получали отказы из-за неправильного оформления ходатайств: не уплачен гербовый сбор, неудачно выбрано помещение, не названо лицо, ответственное за библиотеку и т.д. После обращения к П.И. Макушину все проблемы оказывались решенными в короткие сроки. После 1910 г. ему удалось поставить открытие библиотек на поток. В 1913-1914 гг. в среднем на получение

\footnotetext{
${ }^{1}$ Пронина М.Г. Общество содействия... С. 40.

2 Тимофеева Ю.В. Книжная культура сельского населения Западной Сибири (конец ХІХ - начало ХХ в. Новосибирск, 2012. С. 65; Ивановская Е.В., Сулимов В.С. Библиотеки школ Западной Сибири XIX - начала XX веков. Тобольск, 2018. С. 34-40.

3 ТОКМ. Документы Общества содействия устройству сельских библиотек-читален в Томской губернии. TOКМ 14167/1678.
} 
разрешения об открытии библиотеки уходило от 10 дней до 2-х недель. Так, в с. Барачатское Барачатской волости Кузнецкого уезда ходатайство об открытии библиотеки было подано 10 января 1914 г., а разрешение губернатора последовало 17 января ${ }^{1}$, то есть через неделю.

Из общественных организаций только два макушинских общества - Общество содействия устройству сельских библиотек и Общество содействия устройству разумных развлечений в селах и деревнях Томской губернии (с 1916 г.) - могли работать в сельской местности. Было высказано мнение, что П.И. Макушин в основу деятельности общества положил принцип, которого придерживались земские учреждения центра страны, когда земство выступало соучредителем библиотек, привлекая к их открытию и содержанию местные крестьянские общества ${ }^{2}$. Однако в отличие от земских библиотек, помощь П.И. Макушиным оказывалась не всем подряд, а адресно.

Библиотеки открывались только там, и помощь оказывалась материальная и организационная только тем сельским обществам, которые сами изъявили желание завести библиотеку, где на сельском сходе все население поддерживало открытие библиотеки и обязалось в дальнейшем ее содержать. Размеры библиотеки определялись на основании предварительно собранных данных о числе жителей селения, числе грамотных взрослых и числе учащихся. Число названий книг колебалось между 100 (минимум) и 1000 (максимум), стоимостью от 25 руб. до 250 руб. $^{3}$

Исследователями уже было отмечено, что точную цифру открытых Обществом содействия библиотек назвать трудно ${ }^{4}$. Приблизительность министерских сведений и отсутствие отчетов общества после 1916 г. значительно затрудняет исследование данного вопроса. Мы так до сих пор и не знаем точной цифры открытых в Томской губернии библиотек. По одним сведениям, до 1919 г. Общество учредило 571 бесплатную библиотеку с общим числом книг $180000^{5}$, по другим - к 1919 г. в 600 сельских библиотеках-читальнях находилось до 400 тыс. книг, которыми пользовались многие тысячи сельских читателей 6 . Как бы то ни было, результаты успешной работы Общества содействия очевидны.

Подводя итог, можно сказать, что библиотечная сеть в Томской губернии возникла благодаря личной инициативе и частным капиталовложениям. Источником инициативы выступили не государственные чиновники и не местное самоуправление, а П.И. Макушин как предприниматель и общественный деятель. Даже Духовное ведомство и Министерство народного просвещения в деле создания библиотек в Сибири предпочитали прибегать к помощи Общества содействия. Благодаря уважению и доверию, каким П.И. Макушин пользовался со стороны И.Д. Сытина и российских книгоиздателей вообще, для развития сибирских библиотек удалось получить инвестиции из центра. При посредстве Общества содействия устройству сельских бесплатных библиотек-читален в Томской губернии столичные книгоиздатели не только помогали развитию просвещения в народе, но и одновременно продвигали свой товар.

Многие реалии дореволюционной России начинают изучаться по-новому, что-то из прошлого опыта вполне применимо и в наши дни. Особенно это касается выработки новых механизмов взаимодействия государства, общества и бизнеса. П.И. Макушин и И.Д. Сытин оказались среди тех немногих предпринимателей, которые считали просвещение основой социального прогресса и повышения благосостояния народа. В данном случае просветительские цели совпали с задачами и частными интересами книгоиздателя и книготорговца. Используя не мотив благотворительности, но коммерческий расчёт, готовность дальновидных предпринимателей вкладываться в дела, сулящие выгоду не сегодня, но завтра, П.И. Макушину удалось включить

\footnotetext{
${ }^{1}$ ГАТО. Ф. 3. ОП. 67. Д. 212. Л. 1-4.

2 Попов Д.И. Культурно-просветительные общества в Сибири в конце XIX - начале XX вв. Омск, 2006. С. 80.

${ }^{3}$ Краткий очерк... С. 4.

${ }^{4}$ Пронина М.Г. Общество содействия... С. 44.

${ }^{5}$ Настольный календарь на 1919 г. / под ред. М.Н. Пинегина. Томск, 1919. С. 137.

6 Войтик П.Д. Библиотечное общество в Западной Сибири // Из истории книги, библиотечного дела и библиографии в Сибири. Новосибирск, 1969. С. 112.
} 
И.Д. Сытина и других российских книгоиздателей в благородное дело создания сети сельских библиотек, угверждения книги как неотъемлемой части жизни крестьян того обширного региона, где он жил и работал.

Статья поступила в редакияию 28.09.2018 2.

\section{Лumepamypa}

Войтик П. Д. Библиотечное общество в Западной Сибири // Из истории книги, библиотечного дела и библиографии в Сибири. Новосибирск, 1969. С. 106-112.

Есипова В.А., Карташова Т.П. «На страже закона и нравственности»: к вопросу о регламентации чтения в Томской губернии в конце XIX - начале XX в. // Текст. Книга. Книгоиздание. 2016. № 2(11). С. 96-109.

Зверева К. Е., Зверев В. А. Как Сибирь училась читать: школа, грамотность и книга в Русской деревне конца XIX - начала XX века. Новосибирск: НГПУ, 2013. 237 с.

Ивановская Е.В., Сулимов В.С. Библиотеки школ Западной Сибири XIX - начала XX веков. Тобольск, 2018. 74 с.

Карташова Т.П. Томские издания произведений Л.Н. Толстого // Лев Толстой и время. Томск: Изд-во Том. ун-та, 2010. С. 253-257.

Колосова Г.И. «Свидание с Толстым»: из воспоминаний П. И. Макушина // Лев Толстой и время. Томск, 2001. С. 251-252.

Очерки истории книжной культуры Сибири и Дальнего Востока. Новосибирск, 2000. Т. 1. 316 c.; 2001. Т. 2.367 с.

Попов Д. И. Культурно-просветительные общества в Сибири в конце XIX - начале XX вв. Омск : изд-во ОмГУ, 2006. 512 с.

Пронина М.Г. Общество содействия устройству сельских бесплатных библиотек-читален в Томской губернии // Книжное дело Сибири и Дальнего Востока в XIX - XX веках. Новосибирск, 1986. С. 39-50;

Тимофеева Ю.В. Библиотеки Общества содействия устройству сельских бесплатных библиотек-читален в Томской губернии (1901-1919 гг.) // Библиотековедение. Москва, 2017. Т. 66, № 4. С. 443-450.

Тимофеева Ю.В. Источники финансирования библиотек, учрежденных с помощью Общества содействия устройству сельских бесплатных библиотек-читален в Томской губернии (1901-1919 гг.) // Библиотековедение. 2018. Т. 67, № 1. С. 91-101. DOI: 10.25281/0869-608X-2018-67-1-91-101.

Тимофеева Ю.В. Книжная культура сельского населения Западной Сибири конца XIX начала XX в.: историография вопроса // Известия Алтайского гос. ун-та. 2010. № 4/1. С. 249-253.

Тимофеева Ю.В. Книжная культура сельского населения Западной Сибири (конец XIX начало XX в. Новосибирск, 2012. 192 с.

\section{References}

Esipova V.A., Kartashova T.P. «Na straje zakona I nravstvennosti»: k voprosu o reglamentatsii chteniya v Tomskoy gubernii v kontse XIX - nachale XX v. [«On Guard of Law and Morality»: on reading regulation in Tomsk province in the late 19th - early 20th century]. Tekst. Kniga. Knigoizdanie = Text. Book. Publishing, 2016, \# 2 (11), pp. 96-109.

Ivanovskaya E.V., Sulimov V.S. Biblioteki shkol Zapadnoy Sibiri XIX - nachala XX vekov [Libraries of Western Siberia schools XIX - early XX century]. Tobolsk, 2018. 74 p.

Kartashova T.P. Tomskie izdaniya proizvedeniy L.N. Tolstogo [Tomsk editions of works by L.N. Tolstoy]. Lev Tolstoy I vremya = Leo Tolstoy and time. Tomsk: Tomsk University Press, 2010. Pp. 253-257. 
Kolosova G.I. «Svidanie s Tolstim»: iz vospominaniy P.I. Makushina [«Meeting with Tolstoy»: from the memoirs of P.I. Makushin]. Lev Tolstoy I vremya = Leo Tolstoy and time. Tomsk, 2011. Pp. 251-252.

Ocherki istorii knizhnoj kul'tury Sibiri i Dal'nego Vostoka. [Sketches of historical book culture of Siberia and Far East]. Novosibirsk, 2000. T. 1. 316 s.; 2001. T. 2. 367 s.

Popov D.I. Cul'turno-prosvetitel'nie obsh'estva v Sibiri v kontse XIX - nachale XX vv [Cultural and educational societies in Siberia in the late XIX - early XX centuries]. Omsk: OmSU University Press, 512 p.

Pronina M.G. Obsh'estvo sodeystviya ustroystvu sel'skih besplatnih bibliotek-chitalen v Tomskoy gubernii [Society for the Promotion of Free Rural Libraries in the Tomsk Province]. Knijnoe delo Sibiri I Dal'nego Vostoka v XIX - XX vekah = Book publishing in Siberia and the Far East in the XIX - XX centuries. Novosibirsk, 1986. Pp. 39-50.

Timofeeva Yu.V. Biblioteki obch'estva sodeystviya ustroystvu sel'skih besplatnih bibliotekchitalen v Tomskoy gubernii (1901-1919 gg.) [Libraries of the Society for the Promotion of Rural Free Libraries in Tomsk Province (1901-1919)]. Bibliotekovedenie = Librarianship. 2017. Vol. 66, 2017. №4, pp. 443-450.

Timofeeva Yu.V. Istochniki finansirovaniya bibliotek, uchrezhdennyh $\mathrm{s}$ pomoshch'yu Obshchestva sodejstviya ustrojstvu sel'skih besplatnyh bibliotek-chitalen v Tomskoj gubernii (1901-1919 gg.) [Sources of finance for libraries established with the help of Soviety for promoting free rural libraries at Tomsk governorship (1901-1909] // Bibliotekovedenie. 2018. Vol. 67, № 1. S. 91-101. DOI: 10.25281/0869-608X-2018-67-1-91-101.

Timofeeva Yu.V. Knizhnaya kul'tura sel'skogo naseleniya Zapadnoj Sibiri konca XIX - nachala XX v.: istoriografiya voprosa // Izvestiya Altajskogo gos. un-ta. 2010. № 4/1. S. 249-253.

Timofeeva, Yu.V. Knizhnaya kul'tura sel'skogo naseleniya Zapadnoy Sibiri (konets XIX nachalo XX v.) [The Book Culture of the Rural Population of Western Siberia (the late 19th - early 20th centuries)]. Novosibirsk: TsRNS, 2012. 192 p.

Voitic P.D. Bibliotechnoe obshestvo v Zapadnoy Sibiri [Library Society in Western Siberia] Iz istorii knigi, bibliotechnogo dela I bibliografii $v$ Sibiri $=$ From the history of books, librarianship and bibliography in Siberia. Novosibirsk, 1969. Pp. 106-112.

Zvereva K. E., Zverev V. A. Kak Sibir' uchilas' chitat': shkola, gramotnost' i kniga v Russkoj derevne konca XIX - nachala XX veka. Novosibirsk: NGPU, 2013. 237 s. 